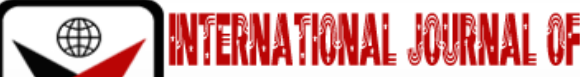

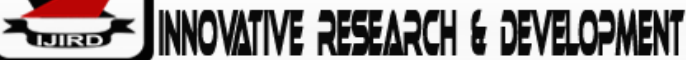

ISSN 2278-0211 (Online)

\section{Educational Wastage in Colleges of Education in Nigeria: Situational Report}

\author{
Ebenezer Taiwo Adu \\ Senior Lecturer, Educational Foundations and Management, \\ Bamidele Olumilua University of Education, Science and Technology, Nigeria \\ Dr. Johnson Tayo Adigun \\ Senior Lecturer, Educational Foundations and Management \\ Bamidele Olumilua University of Education, Science and Technology, Nigeria
}

\begin{abstract}
:
The research examined the situation of educational wastage in Colleges of Education. This study adopted descriptive research design of survey type. The population for this study comprised all the 70 Colleges of Education in existence between 2013/2014 and 20117/2018 in Nigeria. These Colleges of Education were owned by both the federal and state governments in Nigeria. There were 26 federal and 50 states owned Colleges of Education located in all the six geo-political zones of the country. The sample for this study comprised of twelve (12) Colleges of Education. The respondents were all the 191 heads of departments drawn from these twelve (12) Colleges of Education in three geopolitical Zones. The sample technique involved multi-stage, stratified random and purposive samplings. The instrument used was a self-developed inventory titled 'Inventory on wastages in Colleges of Education in Nigeria' (IWCOEN). The instrument was subjected to screening by experts in Educational Management and Test and Measurement. Data collected were analysed using descriptive statistics such as cohort and percentages. The findings of the study revealed $3.01 \%$ stagnation rate in year one and $2.37 \%$ in year two, the dropout rate was $2.08 \%$ in year one while year two had 1.54\%. It was concluded that there was high wastage rate in The Colleges of Education in Nigeria. Based on the conclusion, it was therefore recommended that management of Colleges of Education should provide enabling environment for the students to learn and that the policy of five maximum years for students should be reduced to allow those that could no graduate within the approve years to privilege of spending more years.
\end{abstract}

Keyword: Cohort, Drop out and stagnation, wastage

\section{Introduction}

Wastage is the situation in which individual fails to complete a course of study or abandon a job for which he is programmed. Wastage occurs when an investment does not produce either its desired or anticipated results at a scale considerably lower than it has set for itself. Brimar and Paul (1981) and Adu (2010) remarked that wastage revolves around the following forms:

- When the country fails to provide education to all school age.

- Failure to recruit children to further their education.

- Failure to hold children within the system.

- Failure of the system to set appropriate objectives

- Inefficiency in the achievement of objective.

There are three forms of wastage namely: year-by-year dropout of pupils, the ultimate failure at the examination of those who survive up till the final year when the examination is taken and year-by-year repetition of students (Adesina, 1983). But George (1988) argued that, wastage in education are those uncertificated school leavers who left the school system before the completion of the course. However, they argued further that wastage may occur between the grades, that is, those pupils who repeat the grade and those who drop-out of the system between the grades in question. This is in line with the view of Durosaro (1985) that within a system whatever happens to any student that will cost him or her extra period to meet-up is part of wastage. This is because in higher institutions, some students may fail a course, though such a course does not hinder him from moving to the next class, yet he has to repeat such a course. As the candidate repeats such a course, wastage occurs. This is because the teaching has been paid for at that point in time. Not only that, time and effort has been wasted. He needs extra effort, time and even finance to meet up with his colleagues.

In another dimension, Ade-Ajayi, Asubiojo and Olaniyi, (2019) argued that wastage is a fluctuation in which an individual fails to complete a course of study or abandon a job for which he is programmed. This argument supported the early view of Aboderin (1999) who reported that wastage in education applies to those features in the system that 
contribute to poor cost effectiveness such as pupils having to repeat a year in the same class and those abandoning a course before they completing it, and the brain drain which results from for better working conditions.

The high manpower needs of any country depend on the output of the tertiary level of education in which Colleges of Education are among. Ekanem (2016) posited that any foreseeable or non-foreseeable problems at this level should be of tremendous concern to government, educational planners, and administrators and to the industrial and other national development-oriented persons. He argued further that most time wastage is always considered as a negative factor to educational system. Transmission of values, culture, ideals and aspirations of national development efforts revealed in education is an investment on human resources. Any form of wastage at the secondary school level (which is peculiar to institution) is a major wastage of human resources.

Oyetakin, \& Odunayo (2013) revealed that government have invested huge amount of money out of the national budget to education and the parents have also invested physical and financial resources, time and effort on the human populace in order to acculturate, educate or establish some national norms in the people and at the same time produce the manpower requirements (in education) of the nation. On this note, the society is expecting that the output (N.C.E. graduates) would fit into its area of specialization (teaching at primary school level). Ekanem (2016) therefore holds the belief that wastage within the school system is loss of investment on education since the same money would have been used to develop other sectors of the economy.

In consonance with the above submission, Fauzia and Kuchah (2016) argued that wastage occurs in various form. In the first instance, wastage exists when a country fails to provide universal education for her citizens when she leaves large quantities of her human resources undeveloped. This may be as a result of poverty of the country to make such provisions. But Ade-Ajayi, Asubiojo and Olaniyi, (2019) argued that the world as a whole is poor, therefore such a country lacks focus. However, Durosaro, (1985) argued that any student who does not complete secondary education is a drop-out and such has reduced the flow and wasted the resources expended because the manpower envisaged for the development of the nation is unrealizable from the individual. He posited further that since only $20 \%$ to $30 \%$ senior secondary school leavers ever go to the university, it is a waste of both human and financial resources. This is supported by Ade-Ajayi, Asubiojo and Olaniyi, (2019) that for inability of any student to succeed in any exam, the fund expended on teachers' salaries, construction and rehabilitation of school building and even the time spent by the teachers and students are wasted. This form of wastage also exists in those countries that provide universal primary and secondary education but have not achieved 100\% enrolment rate of school-age children (Ekanem, 2016).

At variance to the above Ogun (2001) argued that wastage exist in most of the developing countries where primary and secondary school attendance is compulsory. However, failures to recruit these children into the system of higher education after compulsory secondary education where the facilities exist represent some waste. This occurred in Nigeria after the introduction of universal primary education in which primary education was made free and compulsory for the school age. But years after most of the graduates could not go further in their education due to one factor or the other ranging from poor teaching method, inadequate funds to students' poor attitude to work (Aworanti 2000).

The third form of wastage is the children already in the school system, leaving it before the successful completion of any particular cycle in which they are enrolled for. This might be willingly or by force. Ekanem (2016) called the situation by which those who leave school voluntarily and those who are forced to leave because of poor grades or for disciplinary reason 'drop-out'. This is the incident of dropping-out of school or student alterations. This phenomenon leads to a loss of talents to the country, and under-utilization of facilities and resources allocated to education.

In addition, Ajayi (1995) argued that wastage occurs when stated set of educational objectives is not appropriate to the economic, political, cultural and social needs of the country. The educational system may remain high, but failure to achieve balance between the necessity of education to the individual needs of the children and the production of trained manpower needed for economic and social development at the right time represents the ineffectiveness of the educational system.

Another concept of educational wastage as perceived by Ekanem (2016) is that when the input and output are compared, it was realized that the real output much more fell below the expected output. In educational institutions, the failure of students admitted into the educational system to achieve the standards set for them or the inability of any student to meet up with the standard set for him in particular class or grade will make such a candidate to repeat that class or course. It is observed that if such a student eventually passes from that particular cycle, he is no longer within the minimum time for the completion of the cycle. Any student, who repeats a class or a course though, completes the programme, the additional year spent, has made him to occupy two-year grade where the system plans only one-year grade.

\subsection{Statement of the Problem}

One major problem confronting Colleges of Education in Nigeria is that the total number of students enrolled for the academic session does not graduate at the specified period which has a lot of implications on the system. Wastages across Colleges of Education in Nigeria have constituted a management problem and a drain at the limited resources in the Nigeria Colleges. Experience shows that some of these students repeat classes/courses because of poor academic performance arising from long absence from school while some of the students eventually dropout of school and the huge public expenditure on students who do not attend school regularly and those who dropout from school system affects the rates of outputs. Only few progress to the next level. Many get themselves moving to higher class in spite of backlogs of carryover courses. It seems as if students are no more interested in the academic work. As a result of this research was set to examine the wastage rates in The Colleges of Education in Nigeria. 


\subsection{Purpose of the Study}

One major problem facing the educational sector in the country is the problem of educational wastages caused by dropout, repetition and failure. The present study is designed to explore the problems and cost of wastages in education the researcher therefore attempted to specifically investigate the situation of wastage rate in the Colleges of Education using 2013/2014 cohort.

\subsection{Research Questions}

For the purpose of this research, the following questions were raised:

- What is the progression rate of 2013/2014 cohort in selected Colleges of Education in Nigeria?

- What is the stagnation rate of 2013/2014 cohort in selected Colleges of Education in Nigeria?

- What is the dropout rate of 2013/2014 cohort in selected Colleges of Education in Nigeria?

- What are the wastage rates in the Colleges of Education in Nigeria between 2013/2014 and 2017/2018 sessions?

\section{Methodology}

This study adopted a descriptive research design of survey type. The population for this study comprised all the 76 Colleges of Education in existence between 2013/2014 and 20117/2018 in Nigeria. These Colleges of Education were owned by both the federal and state governments in Nigeria. There were 26 federal and 50 states owned Colleges of Education located in all the six geo-political zones of the country.

The sample for this study comprised of twelve Colleges of Education. The respondents were the 191 heads of departments drawn from these twelve (12) Colleges of Education in three geo-political Zones. The three geo-political zones are; South-West, south-East and North-Central. Sample of the population was drawn in such a way that every member of the population had a statistical chance of being selected. The sample technique involved multi-stage, stratified random zaand purposive samplings. As such, the first stage was the selection of three (3) geo-political zones through stratified random sampling technique, second stage was the selection of twelve (12) Colleges of Education in Nigeria, and the third stage was the selection of heads of departments through purposively sampling technique. It was purposively selected because only the heads of departments could respond to the data requested by the researcher. The instrument used was a self-developed inventory titled 'Inventory on wastages in Colleges of Education in Nigeria' (IWCOEN) used to sought information on number of students that progressed to higher level, number of stagnations, dropout and graduate outputs in each department in the Colleges of Education sampled. The instrument was subjected to validation by exerts in Educational Management and Test and Measurement, based on their comments, the instrument was restructured, corrected and hence refined in order to meet the face and content validities. The instrument was administered through the help of the research assistants who distributed all the copies of the inventory to the heads of the departments in the Colleges of Education to ensure quick return of the instrument. In analysing the data collected for the study, descriptive statistics such as frequency counts, percentages mean and cohort analysis were used.

\section{Results and Discussions}

\subsection{Descriptive Analysis}

- Question 1: What is the progression rate of 2013/2014 cohort in selected Colleges of Education in Nigeria? In answering this question, data on the number of students' progression in 2013/2014 to 2017/2018 were collected from the heads of academic departments of the sampled Colleges of Education through their responses to the inventory. Data on progression of part one to two and part two to three were collected. The data collected were analysed using frequency count, percentages through the use of percentages. The findings are presented in table 1 :

\begin{tabular}{|c|c|c|c|c|c|}
\hline Session & Year one & Year two & Year three & Extra one Year & Extra two year \\
\hline & $\%$ & $\%$ & $\%$ & $\%$ & $\%$ \\
$2013 / 2014$ & 94.56 & 96.30 & 78.96 & 16.59 & 7.93 \\
$2014 / 2015$ & 94.78 & 95.82 & 42.64 & 51.55 & 10.26 \\
$2015 / 2016$ & 94.88 & 96.04 & 43.19 & 17.57 & 4.80 \\
$2016 / 2017$ & 96.14 & 95.68 & 39.97 & 4.16 & 5.00 \\
$2017 / 2018$ & 95.23 & 93.51 & 44.70 & 4.54 & 4.44 \\
\cline { 1 - 3 } Average & 95.12 & 95.40 & 49.89 & 18.88 & 6.49 \\
\hline
\end{tabular}

As indicated in table 1, the average rate of progression in year 1 is $95.12 \%$. It increases to $95.40 \%$, the rate of progression further decreases to $49.89 \%$ in year three. The average progression rate of $18.88 \%$ is recorded among students that spent extra one year but drops to $6.49 \%$ among students that spent maximum five years. The graphical representation of the progression rate is indicated in Figure 1. 


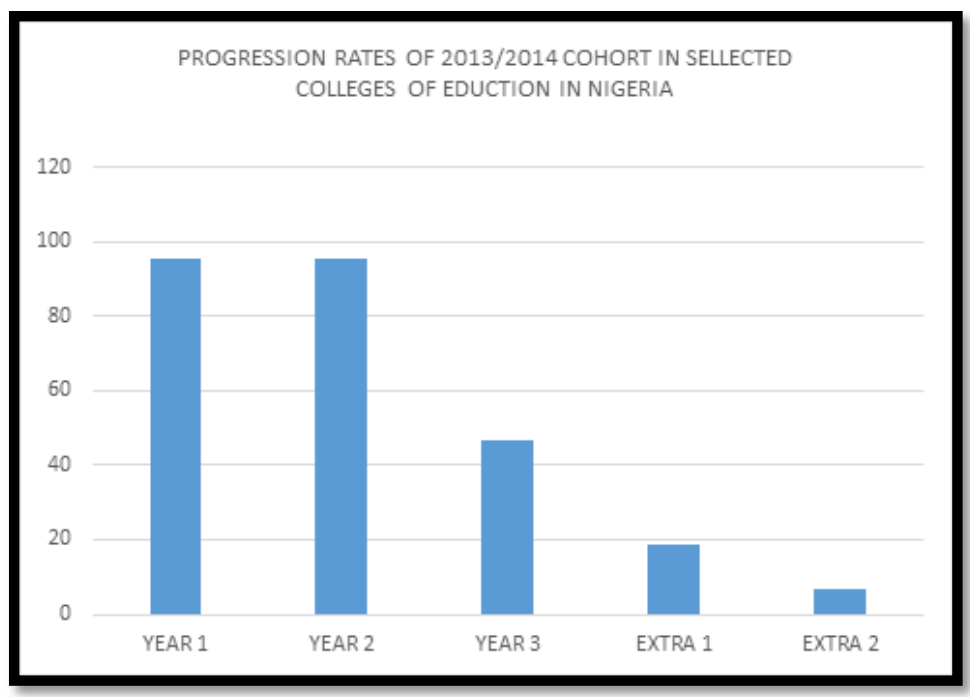

Figure 1: Progression Rate in Colleges of Education between 2013/2014 and 2017/2018session

In Figure 1, the graph shows an upward movement trend in the stagnation rate of students in the Colleges of Education from year one to two but moves to downward from year three up till the fifth. The lowest average progression rate $(3.28 \%)$ is recorded against students that spent maximum five-year years.

Question 2: What is the stagnation rate of 2013/2014 cohort in the selected Colleges of Education in Nigeria?

In answering this question, data on the number of students on stagnation in 2013/2014 to 2017/2018 were collected from the heads of academic departments of the sampled Colleges of Education through their responses to the inventory. Data on stagnation of part one to two and part two to three were collected. The data collected were analysed using frequency count, percentages through the use of relevant Formula as indicated in chapter three. The findings are presented in table 2:

\begin{tabular}{|c|c|c|c|c|c|}
\hline Session & Year one & Year two & Year three & Extra one Year & Extra two year \\
\cline { 1 - 5 } $2013 / 2014$ & $\%$ & $\%$ & $\%$ & $\%$ & $\%$ \\
$2014 / 2015$ & 3.26 & 2.11 & 20.26 & 71.49 & 55.98 \\
$2015 / 2016$ & 2.93 & 2.95 & 56.00 & 24.61 & 32.95 \\
$2016 / 2017$ & 3.35 & 4.56 & 57.62 & 74.53 & 64.19 \\
$2017 / 2018$ & 2.88 & 38.46 & 53.52 & 80.32 & 79.41 \\
\cline { 1 - 1 } Average & 3.97 & 13.24 & 46.94 & 69.45 & 81.61 \\
& 3.28 & & & & 62.83 \\
\hline
\end{tabular}

Table 2: The Students' Stagnation Rates for 2013/2014 and 2017/2018 Sessions in Colleges Of Education

As indicated in table 2, the average rate of stagnation in year 1 was 3.28\%. It was increased to $13.24 \%$, the rate of stagnation further increased to $46.94 \%$ in year three. The highest average stagnation rate of $69.86 \%$ was recorded among students that spent extra one year but dropped to $62.83 \%$ among students that spent maximum five years.

The graphical representation of the stagnation rate is indicated in Figure 3.

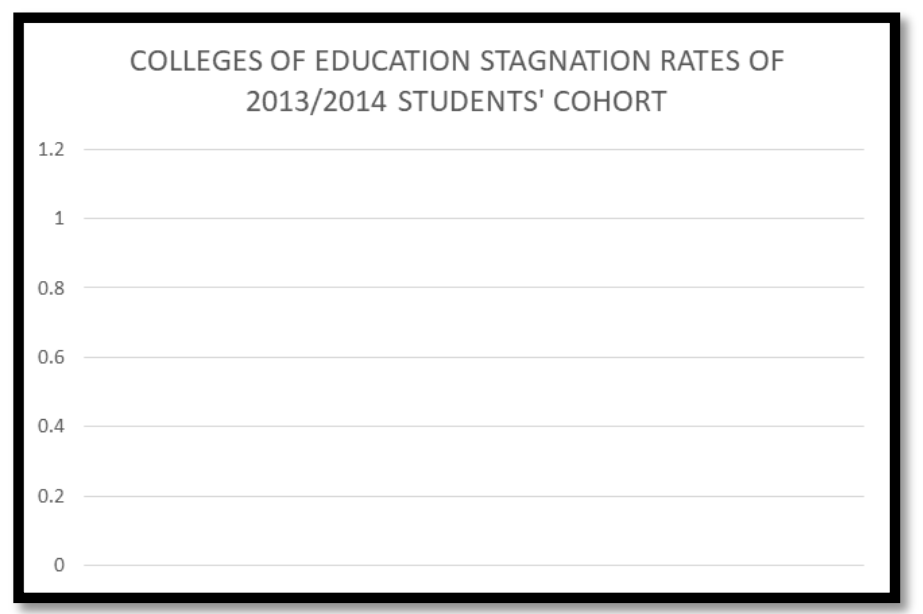

Figure 2: Student's Stagnation Rates for 2013/2014 and 2017/2018 Sessions 
In Figure 2, the graph shows an upward movement trend in the stagnation rate of students in the Colleges of Education. The lowest average stagnation rate (3.28\%) was recorded for year one while highest stagnation rate (69.86\%) was recorded after spending four years. This shows that the higher the level of the class the higher the stagnation rate. Question 3: What is the dropout rate of 2013/2014 cohort in selected Colleges of Education in Nigeria?

In answering this question, data on the number of students that dropped out in 2013/2014 to 2017/2018 were collected from the heads of academic departments of the sampled Colleges of Education through their responses to item 9 of the inventory in appendix II. Data on dropout of students from year one to two, year two to three, and those that spent extra one or two years were collected. The data collected were analysed using frequency count and percentages through the use of relevant formula as indicated in chapter three. The findings are presented in table 3 :

\begin{tabular}{|c|c|c|c|c|c|}
\hline Session & $\begin{array}{c}\text { Year one } \\
\%\end{array}$ & $\begin{array}{c}\text { Year two } \\
\%\end{array}$ & $\begin{array}{c}\text { Year three } \\
\%\end{array}$ & $\begin{array}{c}\text { Extra one Year } \\
\%\end{array}$ & $\begin{array}{c}\text { Extra two year } \\
\%\end{array}$ \\
\hline $2013 / 2014$ & 2.18 & 1.59 & 0.78 & 11.92 & 36.09 \\
\hline $2014 / 2015$ & 1.49 & 2.04 & 1.36 & 23.84 & 56.79 \\
\hline $2015 / 2016$ & 2.32 & 1.87 & 9.19 & 7.90 & 31.01 \\
\hline $2016 / 2017$ & 0.99 & 2.12 & 2.89 & 5.52 & 15.59 \\
\hline $2017 / 2018$ & 1.98 & 3.89 & 1.78 & 7.01 & 13.95 \\
\hline Average & 1.79 & 2.31 & 3.19 & 11.24 & 30.66 \\
\hline
\end{tabular}

Table 3: Dropout Rates for 2013/2014 to 2017/2018 Sessions in Colleges of Education

As indicated in table 3the average dropout rates were low in all the first three years of study. In year one the average dropout rate was $1.79 \%$. In year two it was $2.31 \%$, it was increased to $3.19 \%$ after spending three years but after spending extra one year the average dropout rate rose to $11.24 \%$. It was recorded that $30.66 \%$ of those that spent maximum five years dropped out without receiving the certificate. This finding shows that there was increase in the dropout rate as students moved to higher classes. Figure 3 shows the graphical representation of the dropout rate in the Colleges.

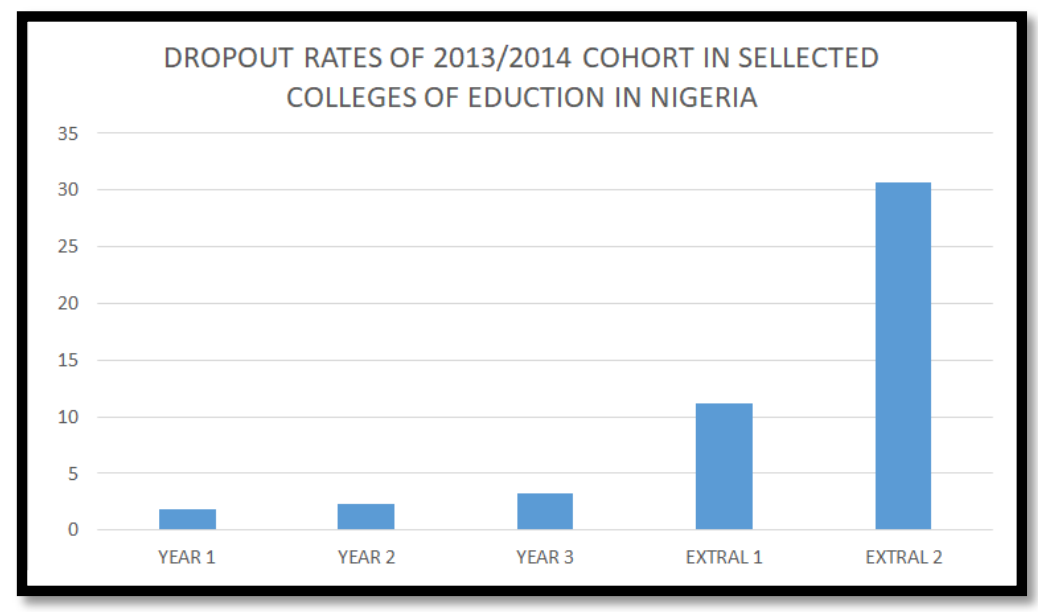

Figure 3: Dropout Rates for 2013/2014 and 2017/2018 Sessions in Colleges of Education

In Figure 3, the graph shows an upward trend in the rate of dropout among students of the Colleges of education. The dropout rate was low in year one and two but increased in year three when it rose to 3.19\% indicating more dropouts at the level. However, the dropout increased to $11.24 \%$ in fourth year while at the fifth year the dropouts increased rapidly to $30.66 \%$ suggesting that those spent extra year constituted greater number of dropouts in the system.

\subsection{Discussions}

The findings of the study which revealed $3.01 \%$ stagnation rate in year one and $2.37 \%$ in year two might be attributed to the policy that did not make any provision for the issue of repetition in high institutions. Those that stagnated might perhaps have done so as a result of illness, financial problem or rustication for a semester or session. Those that stagnated based on academic performance would have done that willingly if they were 'at risk students'. Therefore, these findings corroborated the findings of Ize-Iyamu (1992) and Ayodele (2000) who reported that repetition rate was higher in lower classes. However, the findings negated the findings of Loxley (1991) and Nyikanna (1992) who reported that the incidence of repetition was high in the higher level of schooling in Nigeria.

The findings of this study showed that dropout rates fluctuated within the sessions for year one and year two. But there was high average dropout rate in part one that had $2.08 \%$ as compared to year two that had $1.54 \%$. This contradicts the report of Fauzia and Kuchah (2016) on result allocation and internal efficiency in Colleges of Education in Oyo State which predicted an increase in the drop out in the Colleges. The finding was however in consonance with the findings made by Ekanem (2016) who in a study examined the rate of dropout in high schools which was high. He however revealed that there would be decline in the trend of dropout. On the issue of low dropout in year one found in this study, the findings disagreed with Ejieh (1994) who reported that dropout rate was higher in year one due to the fact that some 
did not have interest on the courses for which they were admitted or engaged in certain work. However, the dropout rate was high among those that spent extra one or two years which indicates that the students might be academically poor. They most have been having carryover courses right from their year one but kept on moving to higher level since no policy mandated them to stagnate in such classes.

The high wastage rate recorded in this study was consisted with the findings of other researchers (Peng and Fetter 1977, Aboderin, 1999, Aworanti, 2008 and Adu, 2019) who revealed that high number of wastages was recorded among students that spent longer years than normal years as a result of inability to meet-up within five maximum five years.

\section{Conclusion}

Thus, it could be concluded that there was high wastage rate in The Colleges of Education in Nigeria and that the rate was higher among those that spent extra two years (failed out)

\section{Recommendation}

Based on the conclusion, it is therefore recommended that management of Colleges of Education should provide enabling environment for the students to learn which would reduce wastage. Also, the policy of five maximum years for students should be removed to allow those that could not graduate within the approve years to have privilege of spending more years so that they can obtain the certificate.

\section{References}

i. Aboderin, J.A (1999): Students' wastage rates in secondary school in Epe L.G.A. Lagos State. Unpublished M.ED Thesis. University of Ilorin.

ii. Ade-Ajayi, Asubiojo and Olaniyi, (2019). Class-size as Correlate of Effective Teaching and Learning Process for Quality Education in Ekiti State Secondary Schools. Ikere Journal of $\quad$ Education. 19 (1) 317-324

iii. Adesina, S. (1983): Education for development. The challenges of the 1980s. In Adesina S., Akinyemi K. and Ajayi K. (eds). Nigerian education trends and issues. Ile - Ife University of Ife.

iv. Adu, E. T. (2019). Analysis of internal efficiency of Colleges of Education in Nigeria. Journal of Religious Studies, Ekiti State University, Ado Ekiti. 4 (2); 44- 50

v. Ajayi, T. (1995): An examination for pupils' withdrawer from the universal primary education (UPE) scheme in Ogun StateOsu journal of educational studies 2 (1), 107.

vi. Aworanti, J. (2000): Assessment of efficiency of the teaching process in technical colleges in Nigeria in J. 0. Fadipe and E. E. Oluchukwu (Eds). Educational planning and administration in Nigeria. Ibadan: NIEPA.

vii. Aworanti,O. A.(2008): A Survey of junior secondary school teachers demand and supply in Edo-State, Nigeria in T. Ajayi,J.O. Fadipe, P. K,Ojedele\& E. E.Oluchukwu(eds.) Planning and administration of UBE in Nigeria, NIEPA.

viii. Ayodele, J. B. (2000): School size, class size, quality correlates of internal efficiency in primary schools in Ondo State, Nigeria. Unpublished Ph.D Thesis, University of Ibadan.

ix. $\quad$ Brimer M. A. \& Paul L. (1971): Wastage in education: A world problem. Paris UNESCO.

X. Durosaro, D. O. (1985): Resource allocation and internal efficiency in Secondary Education in Bendel State,Nigeria. Unpublished Ph.D. Thesis, Ibadan, University of Ibadan.

xi. Ejieh, I. O. (1994): Analysis of wastage in secondary schools in Anambra State. Unpublished Ph.D. Thesis, Benin: University of Benin.

xii. Ekanem, E. E. (2016). Average Class Size Distribution Effects on Students' Social Well-Being in University Teacher Education Programmes in Cross River State, Nigeria. International Journal of Innovative Education Research 4 (3):23-31.

xiii. Fauzia, S and Kuchah, K. (2016). Teaching large classes in difficult circumstances. In Graham, H(Eds) The Routledge Handbook of English Language Teaching. London; Routledge Publishers Pg527

xiv. Ize-Iyamu, P.I. (1992): An Analysis of Pupil Wastage in Bendel State Primary Schools between 1982 and 1987. Unpublished Ph.D. Thesis, University of Benin, Benin City.

xv. Loxley W. (1991): Wastage in education on international Encyclopedia of education U.K. Pergamon press.

xvi. Nyikana, H.K. (1982): Pupil repetition in the primary schools of Ciskei Unpublished Master's Thesis, University of Orange Free State.

xvii. Ogun, M. (2001): Introduction to educational management. Benin Mabogun publishers.

xviii. Oyetakin, A. I. \&Odunayo M. O. (2013). An Analysis of the Cost of Educational Wastages in Nigerian Public Universities: Efficiency in View. Journal of Educational and Social $\quad$ Research 3 (7). 683-689.

xix. Peng, S. S. \& Fetter, W.B. (1978): Variable involved in withdrawal during the first two years of College: preliminary findings from the national longitudinal study of the study class of 1977. American education research journal, 15(3) 361-372. 